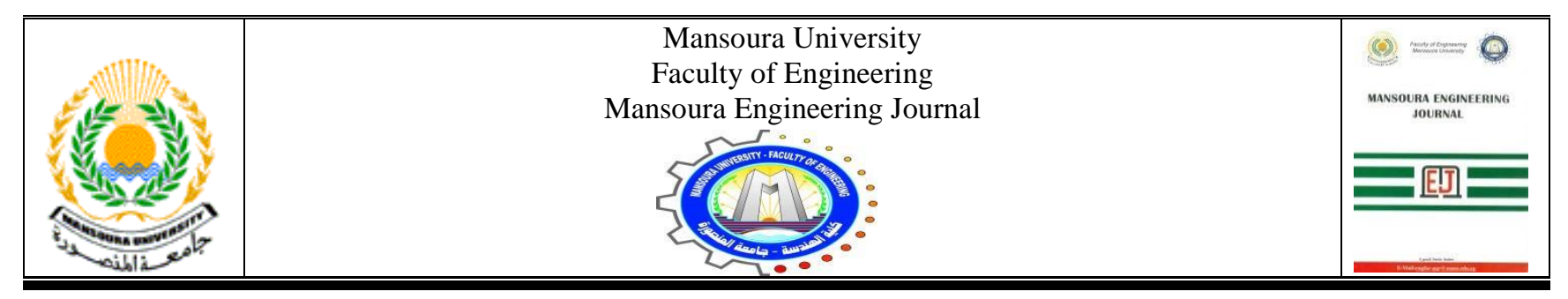

\title{
Using Modern Teaching Strategies to Improve Architectural Design Studio Pedagogy in West Bank
}

\author{
Eman Nabih Shaqour
}

KEYWORDS:
Design Studio
Teaching Strategies
Instructors
Pedagogy
West Bank

\begin{abstract}
The research aims to know the actual use of modern strategies to teach the architecture design studio in the departments of architecture in West Bank universities, to find differences in the use among instructors due to variables (gender, workplace, academic qualification, and the number of experience years and specialty), the extent of knowledge of modern teaching strategies between architecture instructors, and the appropriate teaching strategies for teaching design studio for each level of study. This research's importance lies in spread awareness among instructors about modern design studio teaching strategies and their benefits to the learning process and to change reality and draw attention to new Architectural Design Studio Pedagogy. The descriptive and analytical approach in research implementation. The study tools are interviews and questionnaires. All instructors have demonstrated their use of the following strategies: Brainstorming strategy, Problem-solving strategy, Group work Strategy, Project-based learning, Lecturer's strategy (developed), and Method of scientific trips and visits.
\end{abstract}

\section{INTRODUCTION}

HE education system faced significant challenges in $\mathrm{T}$ light of scientific and technological progress and the knowledge outburst, which had reflection on the educational process in general, and on the university professor role nature in particular. Considering the university professor's role in the current era, it does not lie on teaching students as much as it helps them to learn. Students do not need to gather and accumulate knowledge as much as they need to be proficient in the optimal use of their capabilities to interact with current and future changes. It

Received: (26 December, 2020) - Revised: (22 February, 2021) Accepted: (07 March, 2021)

Corresponding Author: Eman Nabih Shaqour, Lecturer of Architecture Engineering, Faculty of Engineering, Nahda University, Benisuef city, Egypt. (E-mail: eman.shaqoor@nub.edu.eg). helps them to employ the mental skill they possess to face these changes. Design studios experience many problems related to the teaching strategies used. Indoctrination strategies are no longer an appropriate method; instead, they made the educational process in universities incredibly dull, routine, and inertia. When modern strategies developed, the educational process perception changed, the professor and the student's role changed too [1]. Some various definitions and opinions dealt with the word "strategy," and some people view the strategy as a set of teaching procedures which the professor chooses in advance and plans to use during the teaching implementation optimally to effectively achieve the desired teaching goals in light of the available capabilities [2].

As for teaching, it is defined as a professional activity that is accomplished through major processes: planning, implementation, and evaluation, to help students to teach and learn [3]. In light of this, strategy consists of a set of teaching procedures planned by the instructor in advance, as it helps him to implement the teaching in light of the available capabilities to achieve teaching goals. It often includes more 
than one teaching method because there is no single ideal teaching method; instead, there are many methods, one of which is chosen according to specific circumstances [4].

In Palestine, architecture is considered one of the most essential established academic departments in the Engineering Faculties. Architectural education is newly established and began at the first of the eighties of the last century. Thus, architectural education plays an essential and distinct role in Palestinian society's development and progression by providing trained and qualified human energies, especially in construction, planning, and design. Three universities contain the architecture program in the West Bank, one in the north (An-Najah University), (Birzeit University) in the middle, and the (Polytechnic University) in the south [5,6].

In general, the importance of knowing the actual use of modern teaching strategies in design studios in West Bank universities seems clear. It represents a strong indicator of reality and an essential step to improve Architectural Design Studio Pedagogy in West Bank. Teaching strategies in the educational process leads to positive results and contributes to solving many problems despite the limitations of this field's studies. This led many researchers to research, analyze it and search for the best strategies commensurate with its specificity and help the instructors use it properly. This research shed light on the actual use of modern teaching strategies in the architectural design studio. The physical environment is considered important component in learning process because the learning environment in general affects student's creativity [7]. The main place of architecture design course learning is the design studio classroom. Proper interior design of the studio improves the function of learning environment and the confidence of the students involved in the learning process. The physical environment has a direct impact on the satisfaction of the students. Learning environment internal spaces such as classroom has a direct impact on the academic motivation and the social relationships of the students [8].

The research aims to know the actual use of modern strategies to teach the architecture design studio in the departments of architecture in West Bank universities and to find differences in the use among instructors due to variables (gender, workplace, academic qualification, and the number of experience years and specialty). This research's importance lies in spread awareness among instructors about modern design studio teaching strategies and their benefits to the learning process and to change reality and draw attention to new Architectural Design Studio Pedagogy.

\section{ELECTION OF THE RESEARCH PROBLEM}

The sense of the research problem stemmed from several matters, namely the researcher notes during work and study in the West Bank universities that the teaching strategies adopted by instructors are not set, as well as following the traditional teaching strategy, which is a project-solving strategy which indicates the lack of diversity in design studio teaching strategies. The current research problem is determined by answering the following questions:
1) What is the extent of knowledge of modern teaching strategies of the architecture instructors who teach design studio in West Bank universities?

2) What is the actual use of modern teaching strategies in an architecture design studio in the departments of architecture in West Bank universities?"

3) The second question, which states the following: "Are there differences in the degree of using modern teaching strategies in the architecture design studio in the departments of architecture in West Bank universities due to the variables (gender, workplace, academic qualification, number of experience years, and specialization)?" This question will be answered through the following assumptions: There are no statistically significant differences at the significance level $(\alpha=0.05)$.

4) What are the appropriate teaching strategies for teaching design studio for each level of study?

\section{LITERATURE REVIEW}

Many international organizations such as the U.I.A. (International Union of Architects), NAAB (National Architectural Accrediting Board of North America), and RIBA (Royal Institute of British Architects) issue charters for architectural education that confirmed design, skill, and knowledge [9]. Educational sciences consist of subdisciplines such as education environment, methods, tools and psychology, and teaching techniques. Some teaching techniques have been used in design studios, such as narrating lectures, discussing, and asking questions [10]. Architecture Design is a process that involves phases of analytical understanding, critical thinking, and creative decision making [11]. The conventional design studio learning method consists of two main phases, the study phase, which focuses on analyzing and defining the problem than the design stage or problem-solving stage [12]. Conventional teaching design methods, such as a project-type design exercise, focus on theoretical rather than practical learning [13]. Architecture departments develop pedagogical models and new learning methods such as Blended Learning, Problem-Based Learning, Distance Learning, and Work-Based Learning. To offer appropriate architectural education to learners, adapting contemporary educational models is necessary, such as the transition to based-processes learning from a content-centered one, the transition to field training from general education, and leveraging the impact of digital knowledge [14].

Student collaboration and peer-to-peer design studio learning on the design studio's learning strategies lead to either progression or regression. Accordingly, using diversified strategies is essential to offer practical learning experiences [15]. Classroom-based models in design studio learning that disengaged theory from practice proved less efficient than active learning models [16]. Virtual reality as a pedagogic tool has recently positive impact on spatial design [17]. Using inappropriate teaching strategies causes overload on students. Each design phase needs various design factors to achieve goals. Those design factors are design communication techniques (such as the use of technology, Sketching, and 
Physical modeling). Teaching and learning methods (such as Discussion of experiences of well-known architects, Site visits, and Experimental learning). Design studio management strategies (such as Group discussions, Interdisciplinary teamwork, and Realistic design problem [18].

Many researchers consider design studio a process that shapes students' knowledge, skills, and sensitivities by promoting their problem-solving and lateral thinking [12]. Participatory learning experiences are considered a dynamic process that consists of initiating awareness among students, the concept of cultural design, and user participation at the early design process to understand user needs [19]. Architecture schools applied different models to make design studios more efficient. Architecture schools use case problems, the participatory model, the concept-test model, the analogical model, the double-layered, the hidden curriculum, the exploratory model, and the interactional model [20].

Instructors develop various teaching methods to teach design studio, Method which could be implemented Learning by Doing, Incidental Learning, learning by Reflection, CasedBased Teaching, learning by Exploring, and Learning by Arguing [21]. Recent studies have argued a new strategy of teaching architecture design related to tolerate ambiguity by having 'negative capability' engenders the architecture design process brings negative feelings during experiencing states of not knowing [22]. It is essential to incorporate a design-build program for architecture design studios and make students engaged with the community through the participatory approach. This integrating technology will raise awareness for students in professional practice [23]. There are various methods used in teaching compositions to architecture students. These methods include practical training on computer-based activities and methods and educational platforms on the Internet. Practical training activities' strategy is the most effective as it works to help students use trial, error, and intuitive understanding [24].

Through the review of previous studies, we note that the methods used in teaching the Architectural Design Studio are varied and many and are continually being developed to reach the main goal, which is an architect equipped and capable of application and dealing with different working conditions. This study came to add to the results of previous studies by revealing more about the nature of the instructors' use of the modern teaching strategies of the architectural design course. It also seeks to advance architectural education by following clear teaching strategies based on scientific principles that work on building architectural thought. It helps linking academic and practical learning and provides the student with a distinguished level of architectural education in general and design studios in particular. This study is an applied course of an exceptional nature that differs from other courses in various disciplines of engineering sciences.

\section{RESEARCH METHODOLOGY}

The researcher used the descriptive and analytical approach in research implementation to achieve the research objectives, as it is the most appropriate approach type suitable for this research. Because it depends on the reality description or phenomenon as it exists, its analysis, and the relationship's statement between its components and the opinions raised about it. This study adopts an inductive methodology. It starts with a problem definition then a desk study to explore modern strategies used in teaching architecture design studio from previous studies. Results revealed a specific description of the actual situation, which taken into consideration to develop an approach with viable solutions and guidelines

1) The first part of this study consists of a theoretical approach to detect and investigate modern teaching design studio strategies from previous studies to develop the study tool.

2) It uses the Delphi technique [25] to perform interviews with instructors to explore their knowledge and application to these strategies. This technique will help better address the reality of using modern strategies in the teaching design studio in West Bank with its precise nature and particular circumstances to suggest solutions and guide the future pedagogy.

3) Then the applied study involved, and progressed into a survey (questionnaire). The researcher used this survey to determine if there are differences in the degree of using modern teaching strategies in the architecture design studio. The researcher applied the questionnaire to the West Bank universities' architecture departments due to many variables (gender, workplace, academic qualification, number of experience years, and specialization)

\section{A. Research Community}

The research community consisted of all Architecture Departments members (the total number is 25 members who specialized in Architecture or City Planning and participate in teaching the Architectural Design Studio at its various levels in the universities of the south and the center of the West Bank- Palestine.

\section{B. Research Sample}

The research sample consisted of (18) faculty members of the Architecture Engineering Departments who teach the Architectural Design Studio in the West Bank universities. The members specialized in architecture or city planning, and they participate in teaching Design Studio that integrates architectural design and planning for projects that extend horizontally. They were chosen by the intentional Method, as the sample included the entire research community, the research tool (questionnaire) was distributed to all 25 faculty members, and 18 questionnaires were retrieved. Thus, the recovery rate is $72 \%$, which is an acceptable percentage to complete the research. The following Fig. 1 shows the distribution of the research sample according to the research variables. 


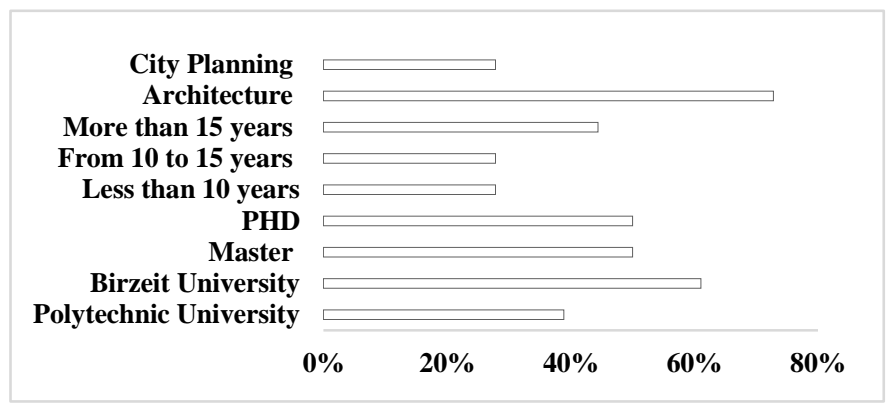

Fig. 1. The distribution of the research sample according to the research variables.

\section{Study tools Validity and Stability}

The tools of this study were interviews with design studio instructors and questioner

1) The interviews: The researcher used the interview tool to study the extent of the instructors' knowledge about modern teaching strategies. The research tool's validity was verified by presenting it to a group of specialized arbitrators, who gave some observations and opinions and indicated the validity and suitability of the questions for this purpose. The stability was measured by the researcher testing the tool prepared on two members of the sample to see its suitability to reveal required, determining the time, and the ability of the faculty member to understand the questions involved. After a week, the two members were re-interviewed by the researcher, using the same questions to determine their stability. The two analyses were identical with a percentage of up to $85 \%$. The researcher made the necessary arrangements for conducting interviews with faculty members in an individual manner

2) The Questionnaire: The validity of it was verified by presenting it to a group of specialized referees, who made some observations and opinions about the scale's validity. The researcher calculated the stability by using the stability of the internal consistency of the respondents' answers to the instrument areas using the stability coefficient of Cronbach alpha on the research community, and the results were as follows in Table 1:

\section{TABLE 1}

\section{STABILITY COEFFICIENTS OF THE QUESTIONNAIRE}

\begin{tabular}{l||l||l} 
Field & $\begin{array}{l}\text { Paragraph } \\
\text { s' number }\end{array}$ & $\begin{array}{l}\text { Stability coefficient } \\
\text { alpha Cronbach }\end{array}$ \\
\hline Actual use of modern strategies & 32 & 0.86
\end{tabular}

As it is evident from the previous table, the value of the stability coefficient for the reality field of using modern teaching strategies was (0.72). This result indicates that the current research tool can reproduce from the current results if re-measuring, researching, and using it again under the same conditions. These values were considered appropriate and acceptable for research purposes, and the objectives for which these fields and their expressions have been set appendix.

\section{Statistical Processing}

The necessary data statistical processing was done by extracting numbers, percentages, arithmetic means, and standard deviations. The research hypotheses were examined at the level $(\alpha=0.05)$, using a t-test for independent samples and a single-variance analysis test using a computer using the SPSS statistical packages program.

Relative Importance Index estimated for interviews results, R.I.I., given below, is used to rank variables within groups:

$$
R I I=\frac{\begin{array}{l}
\text { The the summation of } \\
\text { the total point score }
\end{array}}{5 \times N}
$$

The value of R.I.I. ranges from 0 to 1 , that is, $0 \leq$ R.I.I. $\leq 1$. R.I.I. is used because it fits the purpose of comparing different variables [26].

\section{RESUltS AND DisCUSSION}

After completing the research tools' preparation and application, data were collected, analyzed, and appropriate descriptive statistics were extracted. Delphi Technique used to obtain an opinion from a group of experts (Design studio instructors) related to modern teaching strategies depending on their experience by doing interviews and repeating it.

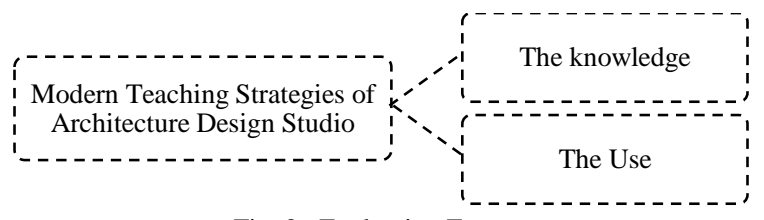

Fig. 2. Evaluation Factors

To answer the first main question, which states the following: "What is the extent of knowledge of modern teaching strategies of the architecture instructors who teach design studio in West Bank universities? The interviews were prepared, and during the interview, the instructors were asked about the strategies they use in teaching design. After getting the answer, the strategies they did not mention were presented to determine if they knew it. Then the answers were coordinated, and the result was the format in the following table according to the number of times the answer is repeated; table 2 clarifies the results.

TABLE 2

MODERn ARChITECTURAL DESIGN STUDIO TEACHING STRATEGIES

\begin{tabular}{|c|c|c|c|c|c|}
\hline \multirow[b]{2}{*}{ No } & \multirow[b]{2}{*}{$\begin{array}{c}\text { Modern } \\
\text { Architectural } \\
\text { Design Studio } \\
\text { Teaching } \\
\text { Strategies }\end{array}$} & \multicolumn{2}{|c|}{ The knowledge } & \multicolumn{2}{|c|}{ The Actual Use } \\
\hline & & $\begin{array}{l}\text { Repeated } \\
\text { Times }\end{array}$ & R.I.I & $\begin{array}{l}\text { Repeated } \\
\text { Times }\end{array}$ & R.I.I \\
\hline 1 & $\begin{array}{c}\text { Brain storming } \\
\text { strategy }\end{array}$ & 18 & $100 \%$ & 18 & $100 \%$ \\
\hline 2 & $\begin{array}{c}\text { Problem solving } \\
\text { strategy }\end{array}$ & 18 & $100 \%$ & 18 & $100 \%$ \\
\hline 3 & $\begin{array}{c}\text { Group work } \\
\text { Strategy }\end{array}$ & 18 & $100 \%$ & 18 & $100 \%$ \\
\hline 4 & $\begin{array}{c}\text { Project-based } \\
\text { learning }\end{array}$ & 18 & $100 \%$ & 18 & $100 \%$ \\
\hline 5 & $\begin{array}{c}\text { Lecturer's strategy } \\
\text { (developed) }\end{array}$ & 18 & $100 \%$ & 18 & $100 \%$ \\
\hline 6 & $\begin{array}{c}\text { Method of } \\
\text { scientific trips and }\end{array}$ & 18 & $100 \%$ & 13 & $72 \%$ \\
\hline
\end{tabular}
INTERVIEWS RESULTS ANALYSIS 


\begin{tabular}{|c|c|c|c|c|c|}
\hline \multirow[b]{2}{*}{ No } & \multirow{2}{*}{$\begin{array}{c}\text { Modern } \\
\text { Architectural } \\
\text { Design Studio } \\
\text { Teaching } \\
\text { Strategies }\end{array}$} & \multicolumn{2}{|c|}{ The knowledge } & \multicolumn{2}{|c|}{ The Actual Use } \\
\hline & & $\begin{array}{l}\text { Repeated } \\
\text { Times }\end{array}$ & R.I.I & $\begin{array}{l}\text { Repeated } \\
\text { Times }\end{array}$ & R.I.I \\
\hline & visits & & & & \\
\hline 7 & $\begin{array}{l}\text { Direct teaching } \\
\text { strategy }\end{array}$ & 17 & $94 \%$ & 16 & $89 \%$ \\
\hline 8 & $\begin{array}{c}\text { Exploratory } \\
\text { method (inductive } \\
\text { and deductive) }\end{array}$ & 17 & $94 \%$ & 15 & $83 \%$ \\
\hline 9 & Seminars & 17 & $94 \%$ & 14 & $78 \%$ \\
\hline 10 & E-learning & 17 & $94 \%$ & 12 & $67 \%$ \\
\hline 11 & Classroom-based & 17 & $94 \%$ & 14 & $78 \%$ \\
\hline 12 & $\begin{array}{l}\text { Using critical } \\
\text { thinking }\end{array}$ & 16 & $89 \%$ & 13 & $72 \%$ \\
\hline 13 & $\begin{array}{c}\text { Active learning } \\
\text { strategy }\end{array}$ & 16 & $89 \%$ & 16 & $89 \%$ \\
\hline 14 & $\begin{array}{c}\text { Virtual reality } \\
\text { tool based } \\
\text { learning } \\
\end{array}$ & 16 & $89 \%$ & 16 & $89 \%$ \\
\hline 15 & $\begin{array}{c}\text { Discussion } \\
\text { strategy }\end{array}$ & 15 & $83 \%$ & 18 & $100 \%$ \\
\hline 16 & $\begin{array}{c}\text { Inquiry-based } \\
\text { learning strategy }\end{array}$ & 14 & $78 \%$ & 11 & $61 \%$ \\
\hline 17 & Experts' interview & 14 & $78 \%$ & 8 & $44 \%$ \\
\hline 18 & $\begin{array}{c}\text { Practical } \\
\text { presentations }\end{array}$ & 13 & $72 \%$ & 9 & $50 \%$ \\
\hline 19 & $\begin{array}{l}\text { Role-playing } \\
\text { strategy }\end{array}$ & 13 & $72 \%$ & 6 & $33 \%$ \\
\hline 20 & Intensive courses & 13 & $72 \%$ & 7 & $39 \%$ \\
\hline 21 & $\begin{array}{c}\text { Based-processes } \\
\text { learning }\end{array}$ & 13 & $72 \%$ & 9 & $50 \%$ \\
\hline 22 & $\begin{array}{c}\text { Programmed } \\
\text { instruction }\end{array}$ & 12 & $67 \%$ & 10 & $56 \%$ \\
\hline 23 & $\begin{array}{c}\text { Small-Group } \\
\text { Teaching Strategy }\end{array}$ & 11 & $61 \%$ & 8 & $44 \%$ \\
\hline 24 & $\begin{array}{c}\text { Work-Based } \\
\text { Learning } \\
\end{array}$ & 11 & $61 \%$ & 6 & $33 \%$ \\
\hline 25 & Tutorial method & 10 & $56 \%$ & 5 & $28 \%$ \\
\hline 26 & $\begin{array}{c}\text { Keeler's Self- } \\
\text { Learning Strategy } \\
\text { or Learning for } \\
\text { Mastery } \\
\end{array}$ & 10 & $56 \%$ & 5 & $28 \%$ \\
\hline 27 & $\begin{array}{c}\text { Laboratory } \\
\text { experiments }\end{array}$ & 10 & $56 \%$ & 4 & $22 \%$ \\
\hline 28 & Blended Learning & 10 & $56 \%$ & 3 & $17 \%$ \\
\hline 29 & $\begin{array}{l}\text { Simulated social } \\
\text { skill training }\end{array}$ & 9 & $50 \%$ & 5 & $28 \%$ \\
\hline 30 & Micro-teaching & 8 & $44 \%$ & 6 & $33 \%$ \\
\hline 31 & $\begin{array}{c}\text { Peer-to-peer } \\
\text { learning }\end{array}$ & 7 & $39 \%$ & 5 & $28 \%$ \\
\hline 32 & $\begin{array}{c}\text { Double layered } \\
\text { learning }\end{array}$ & 6 & $33 \%$ & 2 & $11 \%$ \\
\hline & tal degree & 13.75 & $76 \%$ & 10.8125 & $60 \%$ \\
\hline
\end{tabular}

It is evident from the previous table that the total score of the respondents' attitudes towards the actual knowledge of modern teaching strategies in the architectural design studio is relatively high, as the R.I.I. of the overall instructors is (76\%). And the total score of the respondents' attitudes towards the actual use of modern teaching strategies in the architectural design studio is Medium, as the R.I.I. of the overall instructors is $(60 \%)$. All instructors have demonstrated their knowledge of the following strategies: Brainstorming strategy, Problemsolving strategy, Group work Strategy, Project-based learning, Lecturer's strategy (developed), and Method of scientific trips and visits. $94 \%$ of instructors have demonstrated their knowledge of the following strategies: Direct teaching strategy, Exploratory Method (inductive and deductive), Seminars, E-learning, and Classroom-based Strategy. Instructors have demonstrated a low level of knowledge of the following strategies: Simulated social skill training, Microteaching, Peer-to-peer learning, double-layered learning. And a low level of using the following strategies: Small Group Teaching Strategy, Work-Based Learning, Tutorial method, Keeler's Self-Learning Strategy, Laboratory experiments, Blended Learning, and Simulated social skill training.

The strategies were also formulated within a questionnaire, and instructors were asked to evaluate from 1-3. The results' arithmetic means were calculated, and the analysis showed a considerable correspondence between the questionnaire results and the interviews' results. According to the questionnaire analysis, the following figure shows strategies according to instructors 'knowledge of them, as shown in Table 3.

TABLE 3

MODERN ARCHITECTURAL DESIGN STUDIO TEACHING STRATEGIES QUESTIONNAIRE RESULTS ANALYSIS

\begin{tabular}{|c|c|c|c|c|}
\hline No. & $\begin{array}{c}\text { Design Studio Teaching } \\
\text { Strategies }\end{array}$ & $\begin{array}{l}\text { Mean } \\
\text { value }\end{array}$ & $\begin{array}{l}\text { Standard } \\
\text { deviation }\end{array}$ & Level \\
\hline 1 & Discussion strategy & 2.83 & .38 & High \\
\hline 2 & Using critical thinking & 2.78 & .43 & High \\
\hline 3 & Brain storming strategy & 2.72 & .46 & High \\
\hline 4 & Direct teaching strategy & 2.67 & .59 & High \\
\hline 5 & Problem solving strategy & 2.61 & .50 & High \\
\hline 6 & Group work Strategy & 2.61 & .50 & High \\
\hline 7 & Project-based learning & 2.56 & .62 & High \\
\hline 8 & $\begin{array}{l}\text { Virtual reality tool based } \\
\text { learning }\end{array}$ & 2.54 & & \\
\hline 9 & Lecturer's strategy (developed) & 2.50 & .51 & High \\
\hline 10 & Practical presentations & 2.50 & .51 & High \\
\hline 11 & Inquiry-based learning strategy & 2.50 & .51 & High \\
\hline 12 & Tutorial method & 2.39 & .61 & High \\
\hline 13 & $\begin{array}{c}\text { Exploratory method (inductive } \\
\text { and deductive) }\end{array}$ & 2.33 & .59 & High \\
\hline 14 & Active learning strategy & 2.28 & .57 & Average \\
\hline 15 & Method of scientific trips & 2.22 & .43 & Average \\
\hline 16 & Seminars & 2.22 & .43 & Average \\
\hline 17 & $\begin{array}{c}\text { Small Group Teaching } \\
\text { Strategy }\end{array}$ & 2.17 & .62 & Average \\
\hline 18 & Simulated social skill training & 2.17 & .71 & Average \\
\hline 19 & $\begin{array}{l}\text { Keeler's Self-Learning } \\
\text { Strategy or Learning for } \\
\text { Mastery }\end{array}$ & 2.11 & .58 & Average \\
\hline 20 & Experts' interview & 2.00 & .49 & Average \\
\hline 21 & E-learning & 2.00 & .59 & Average \\
\hline 22 & Role-playing strategy & 1.94 & .42 & Average \\
\hline 23 & Laboratory experiments & 1.89 & .58 & Average \\
\hline 24 & Programmed instruction & 1.72 & .57 & Average \\
\hline 25 & Intensive courses & 1.67 & .69 & Low \\
\hline 26 & Blended Learning & 1.67 & .59 & Low \\
\hline 27 & Work-Based Learning & 1.63 & .49 & Low \\
\hline 28 & based-processes learning & 1.63 & .59 & Low \\
\hline 29 & learning peer-to-peer & 1.60 & .42 & Low \\
\hline 30 & Classroom-based & 1.57 & .58 & Low \\
\hline 31 & Micro-teaching & 1.55 & .57 & Low \\
\hline \multirow[t]{2}{*}{32} & double layered learning & 1.42 & .69 & Low \\
\hline & Total degree & 2.15 & .20 & Average \\
\hline
\end{tabular}

To answer the second main question, which states the following: "Are their differences in the degree of using 
modern teaching strategies in the architecture design studio in the departments of architecture in West Bank universities due to the variables (gender, workplace, academic qualification, number of experience years, and specialization)?" the hypothesis: "There are no statistically significant differences at the level of significance $(\alpha=0.05)$ in the degree of using modern teaching strategies in teaching due to the variables" will be examined by finding the arithmetic means, standard deviations, and T-test results for independent samples, as it is clear the following Table 4.

TABLE 4

THE TESTING RESULTS TO EXAMINE THE DIFFERENCES IN THE DEGREE OF USING MODERN TEACHING STRATEGIES IN DESIGN STUDIO

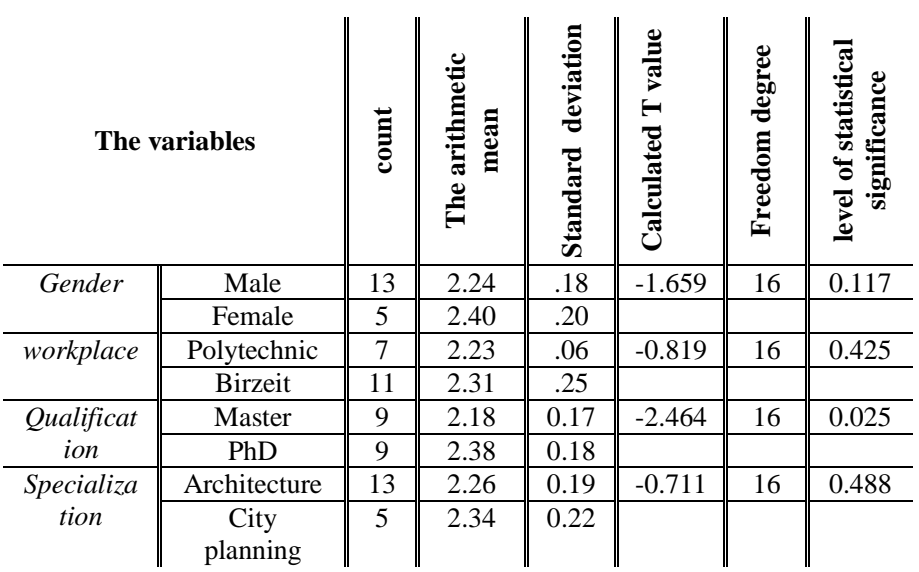

From the above, it is clear to us that there are no statistically significant differences at the level of significance $(\alpha=0.05)$ in the degree of using modern teaching strategies in teaching the architectural design studio from the viewpoint of the instructors due to the gender variable, workplace, and specialization. Thus the previous null hypothesis is accepted. This result indicates West Bank universities' interest and their teaching staff in teaching strategies in the educational process. Its development is at the same level.

From Table 3, it becomes clear that there are statistically significant differences at the level of significance $(\alpha=0.05)$ in the degree of using modern teaching strategies due to the scientific qualification variable (The level of significance is less than 0.05). It concludes the rejection of the previous null hypothesis, as it becomes clear that the differences were in favor of scientific qualification (Ph.D.) with arithmetic mean (2.38) versus scientific qualification (Master) with arithmetic mean (2.18). The researcher attributes this to practical experience in the field of teaching.

The hypothesis: "There are no statistically significant differences at the significance level $(\alpha=0.05)$ in the degree of using modern teaching strategies in teaching the architectural design course. From the viewpoint of the faculty members due to the variable of experience years' number." In order to examine this hypothesis, the arithmetic means, standard deviations and the results of the mono- variance analysis test were extracted, as is evident from the following Table 5:
TABLE 5

THE RESULTS OF MONO- VARIANCE ANALYSIS

\begin{tabular}{|c|c|c|c|c|c|}
\hline $\begin{array}{l}\text { Variance } \\
\text { source }\end{array}$ & $\begin{array}{l}\text { Square } \\
\text { s' total }^{\prime}\end{array}$ & $\begin{array}{c}\text { Freedom } \\
\text { degree }\end{array}$ & $\begin{array}{c}\text { Squares' } \\
\text { average }\end{array}$ & $\begin{array}{c}\text { Calculated } \\
\text { F value }\end{array}$ & $\begin{array}{c}\text { level of } \\
\text { statistical } \\
\text { significance }\end{array}$ \\
\hline $\begin{array}{l}\text { Among } \\
\text { groups }\end{array}$ & 0.329 & 2 & 0.165 & 7.603 & 0.005 \\
\hline $\begin{array}{l}\text { Inside } \\
\text { groups }\end{array}$ & 0.325 & 15 & 0.022 & & \\
\hline Total & 0.654 & 17 & & & \\
\hline
\end{tabular}

From the previous table, it is clear that there are statistically significant differences at the level of significance $(\alpha=0.05)$ in the degree of using modern teaching strategies due to the variable of experience years (the level of significance is less than 0.05). Thus it is concluded that the previous null hypothesis is rejected. The Tykey test was used to study the differences for two-dimensional comparisons, and the following Table 6 shows the results of this test:

TABLE 6

RESULTS OF THE TYKEY TEST ACCORDING TO THE NUMBER OF YEARS OF EXPERIENCE.

\begin{tabular}{c||c||c||c}
$\begin{array}{c}\text { Experience } \\
\text { years number }\end{array}$ & Less than 10 & $\begin{array}{c}\text { From 10 to } \\
\mathbf{1 5}\end{array}$ & $\begin{array}{c}\text { More than 15 } \\
\text { years }\end{array}$ \\
\hline $\begin{array}{c}\text { Less than 10 } \\
\text { years }\end{array}$ & ---------- & $*-0.336$ & -0.065 \\
\hline $\begin{array}{c}\text { From 10 to 15 } \\
\text { years }\end{array}$ & $* 0.336$ & ---------- & 0.271 \\
\hline $\begin{array}{c}\text { More than 15 } \\
\text { years }\end{array}$ & 0.065 & -0271 & -------- \\
\end{tabular}

The previous table results show that the differences favored faculty members with years of experience (from 10-15 years) compared to years of experience (less than 10 years). There weren't any apparent differences in other bilateral comparisons. Table 7 shows the numbers, arithmetic means, and standard deviations using modern teaching strategies in architectural design studio according to the experience years' variable.

TABLE 7

THE NUMBERS, ARITHMETIC MEANS, AND STANDARD DEVIATIONS ACCORDING TO THE EXPERIENCE YEARS' NUMBER

\begin{tabular}{c||c||c||c}
$\begin{array}{c}\text { Experience } \\
\text { years number }\end{array}$ & Number & $\begin{array}{c}\text { The } \\
\text { arithmetic } \\
\text { mean }\end{array}$ & $\begin{array}{c}\text { Standard } \\
\text { deviation }\end{array}$ \\
\hline $\begin{array}{c}\text { Less than } 10 \\
\text { years }\end{array}$ & 5 & 2.16 & 0.23 \\
\hline $\begin{array}{c}\text { From 10 to 15 } \\
\text { years }\end{array}$ & 5 & 2.50 & 0.14 \\
\hline $\begin{array}{c}\text { More than 15 } \\
\text { years }\end{array}$ & 8 & 2.23 & 0.06 \\
\hline Total & 18 & 2.28 & 0.20
\end{tabular}

All the strategies were presented to the participants. They were asked to classify them according to the students' academic level and choose the most appropriate ones for each level. The following results were reached. 


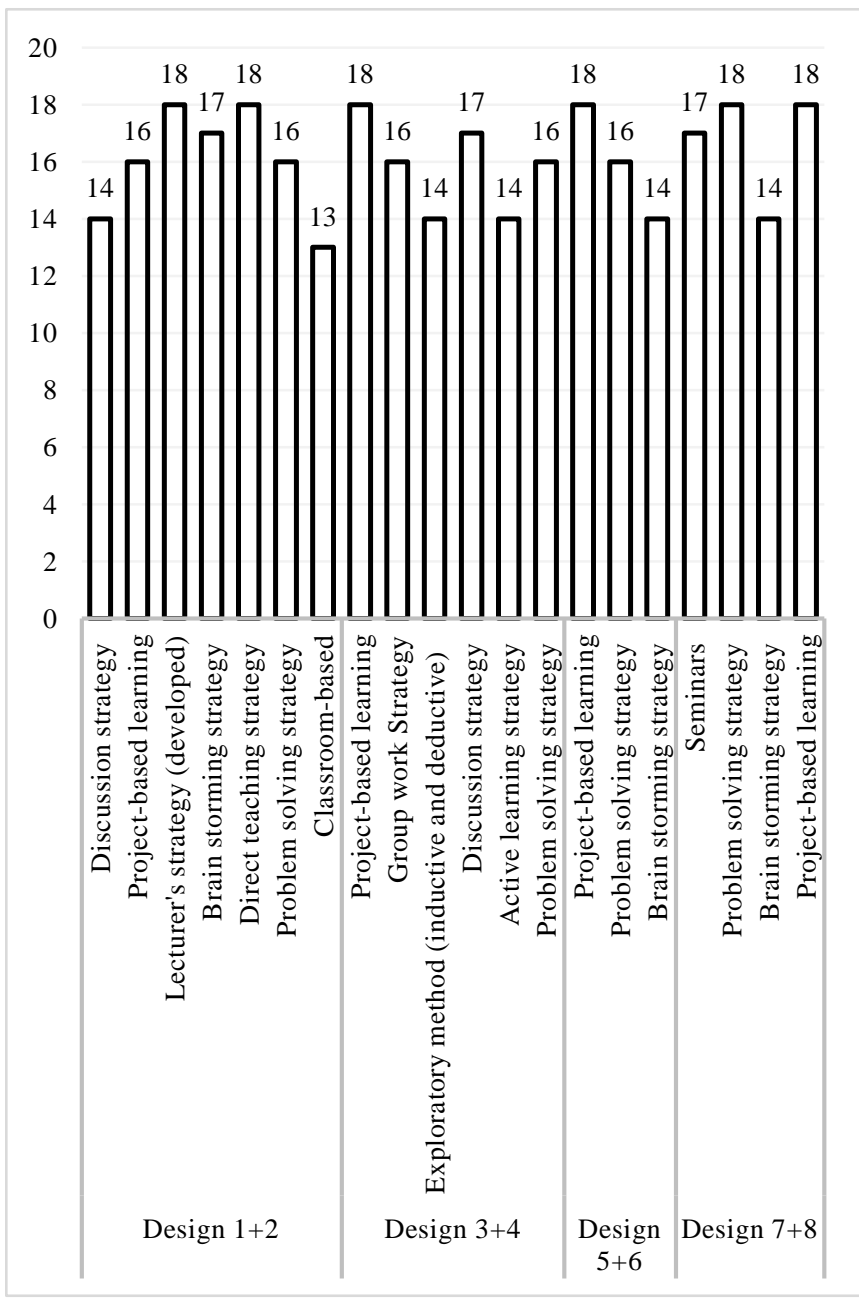

Fig. 3. Evaluation Factors

It is clear from Figure 3 that instructors use ProblemSolving Strategy and Project-Based Learning at all levels. The strategies that give students knowledge used at first levels, such as lecturers, classroom-based, and direct teaching strategies. Strategies that give the student the primary role and rely more on him are used at the last level, like seminars.

\section{Conclusion}

According to the previous results, it is clear that the west bank qualification framework needs a level of skills to adopt application learning strategies and work-related strategies that produce architects relevant to the job market. Design studio teaching must be directed to strategies that integrate theory with practice. Students' workload in the architecture design studio is heavy, and they have eight design courses in Medium (from 8-10 courses). Therefore, each level must be developed to achieve distinct and various goals that gradually towards application and work. The design studio levels are gradual from one to eight, however traditional strategies used from the first level until the last as Project-based learning, Problemsolving strategy, Group work Strategy, and Lecturer's strategy (developed).
Regarding the strategies that link the architect to the work application, their use was weak compared to the strategies that depend on theory. Work-Based Learning, Based-processes learning, Role-playing strategy, Practical presentations, and Experts' interview despite their average knowledge of these strategies are not applied. On the contrary, the results showed their average knowledge of some practical strategies such as Experts' interviews but the low level in using it.

As for the strategies that use technology in teaching, the results varied; for example, the e-learning strategy in the architectural design studio is known and used at a somewhat high level. It is used to disseminate and exchange information between students, instructors, or between students themselves. Students' virtual reality strategy in designing their threedimensional projects, presenting their concepts, discussing and developing them is widely known and used. Students have a good level in the use of architecture applications and programs that tend to be up-to-date.

Regarding the Blended learning strategy in which the traditional and virtual design studio is used together interchangeably and at different rates, it became clear that teachers 'knowledge of it is medium-level. Its use is very little or rare. The conditions are ripe for using such a strategy due to the continuous closures resulting from the political situation and the availability of the Internet and the technical services required to implement it.

Some strategies concern raising the level of students with the average or insufficient level of achievements. The Smallgroup's strategy and Intensive courses, which are used sparingly in place of study, show that all students receive the same level of attention, indicating the production of weak architects that are not suitable for the labor market.

Instructors who obtain a higher academic qualification (Ph.D.) use modern teaching strategies more widely. Their knowledge of them is more comprehensive due to their research experience and access to knowledge more broadly. It may be because they obtain a (Ph.D.) certificate from outside the country and know various educational programs and exchange experiences.

\section{RECOMMENDATIONS}

Curricula for architectural design Pedagogy in West Bank need updating. A comprehensive strategic plan must be developed to use appropriate strategies for each level to raise the level of education outcome, move towards implementation to bridge the gap between education and implementation

\section{REFERENCES}

[1] R. Haqqi, "A general structure of design courses is an experiment in the way of integrating the architectural curriculum," Damascus University Journal of Engineering Sciences, vol. 30, no.1, pp.163-178, 2014.

[2] A. Begum, "Innovative and effective teaching methods for engineering students," SSRG International Journal of Humanities and Social Science, vol. 6, no. 1, pp. 1-3 2019. DOI: 10.14445/23942703/IJHSSV6I1P101

[3] S. Al-Maqati, "Obstacles to applying modern teaching strategies in teaching legal courses at the secondary stage of the curriculum system 
from the teachers' point of view," Journal of Administrative and Human Sciences, vol.13, pp. 17-46, 2018.

[4] R. D. Sarode, "Teaching strategies, styles and qualities of a teacher: a review for valuable higher education," International Journal of Current Engineering and Scientific Research, vol. 5, no. 5, pp. 57-62, 2018.

[5] K. Merai, "Architectural education in universities in Palestinian universities between academic education and community participation", Conference on Engineering Education in Palestine, Polytechnic University, Palestine, 2005

[6] A. Afifi, "Architectural education in Palestine", Master Thesis, Faculty of Architecture, An-Najah University, Nablus, Palestine, 2012.

[7] S. A. Eman, A. E. Hebatallah, "Addressing the urban contextual envelope: an analytical study in architectural design studio" International Journal of Applied Engineering Research, vol.12, no. 18, pp. 7043-7051, 2017.

[8] M. G. Zamar, L. O. Jiménez, A. S. Ayala, "The Impact of the university classroom on managing the socio-educational well-being: a global study, " International Journal of Environmental Research and Public Health, vol.17, no.3, 2020. https://doi.org/10.3390/ijerph17030931

[9] S. S. Masri, "Improving architectural pedagogy toward better architectural design values," Athens Journal of Architecture, vol. 3, no. 2, pp.117-136, 2017, https://doi.org/10.30958/aja.3-2-1

[10] T. Yildirim, A. O. Yavuz, and N. Kırc1, "Experience of traditional teaching methods in architectural design education: mimesis technique," Procedia - Social and Behavioral Sciences, vol. 51, pp. 234-238, 2012. https://doi.org/10.1016/j.sbspro.2012.08.151

[11] A. H. Iavarone, and E. Birer," The concept of limits in architecture as an instructional tool for design education," Journal of Design Studio, vol. 2, no.2, December, 2020. DOI: $10.46474 /$ jds. 814390

[12] R. Priya, P. Shabitha, and S. Radhakrishnan, "Collaborative and participatory design approach in architectural design studios," Social Sciences \& Humanities Open, vol. 2, 2020. https://doi.org/10.1016/j.ssaho.2020.100033

[13] O. S. Iveren and J. Buur," design is a game: developing design competence in a game setting," PDC 02 proceeding of the participatory design conference, Malmo, Sweden, 2002.

[14] M. Masdéu, "The transformative use of work-based learning in the design studio: connecting academia and architectural practice, education, design and practice," Understanding Skills in a Complex World at: Stevens Institute of Technology, New Jersey, U.S.A., pp.86-99, 2019.

[15] S. Park, "Rethinking design studios as an integrative multi- layered collaboration environment," Journal of Urban Design, vol. 25, pp.523550, 2020. https://doi.org/10.1080/13574809.2020.1734449

[16] C. Salazar, I. Arredondo, C. Rodriguez, and D. Huertas, "Active learning in architectural education: a participatory design experience (P.D.E.) in Colombia," International Journal of Art \& Design Education, vol. 39, no.4, 2019. https://doi.org/10.1111/jade. 12280

[17] B. Nisha, "The pedagogic value of learning design with virtual reality," Educational Psychology, vol.39, no.10, pp. 1-22, 2019

[18] A. Soliman, "Appropriate teaching and learning strategies for the architectural design process in pedagogic design studios," Frontiers of $\begin{array}{lllll}\text { Architectural Research, vol. 6, no.2, } 2017 . & \end{array}$ DOI: $10.1080 / 01443410.2019 .1661356$

[19] A. Drain, and E. B. N. Sanders, "A collaboration system model for planning and evaluating participatory design projects," International Journal of Design, vol.13, no. 3, pp. 39-53, 2019. http://www.ijdesign.org/index.php/IJDesign/article/view/3486

[20] A. Salama, "Transformative pedagogy in architecture \& urbanism," 1st ed., Solingen, Germany, UMBAU - VERLAG, 2009
[21] NehaKolhe, "Innovative tools and techniques to teach architecture," International Journal of Engineering Research and Technology, vol. 10, no. $1,2017$.

[22] N. E. Mahmoud, S. M. Kamel, and T. S. Hamza, "Introducing negative capability to design thinking ambiguity tolerance in the design studio", Journal of Engineering and Applied Science, vol. 67, no. 6, pp. 15151534, faculty of engineering, Cairo University, Cairo, 2020. DOI: $10.3846 /$ cs. 2020.9628

[23] N. A. Amer, "Appropriate technology and design-build program in architectural education", Journal of Engineering and Applied Science, vol. 62, no. 6, pp. 507-528, Faculty of Engineering, Cairo University, Cairo, 2015.

[24] Emmi, N., and Buelow, P. V." Teaching structures to architecture students through hands- on activities", Jaubman College of Architectural and Urban Planning, University of Michigan, U.S.A., 2016

[25] H. A. Linstone and M. Turoff, "The delphi method techniques and applications", Murray Turoff and Harold A. Linstone, New Jersey Institute of Technology, U.S.A., 1975. DOI: 10.2307/3150755

[26] M. K. Somiah, G Osei-Poku., and I. Aidoo, "Relative importance analysis of factors influencing unauthorized siting of residential buildings in the sekondi-takoradi metropolis of Ghana," Journal of Building Construction and Planning Research, vol. 3, pp. 117-126, 2015. DOI: $10.4236 /$ jbcpr.2015.33012

\section{Title Arabic:}

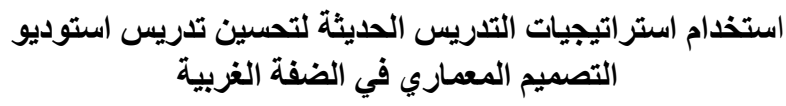

\section{Arabic Abstract:}

يهدف البحث إلى معرفة الاستخدام الفعلي للإستراتيجيات الحديثة

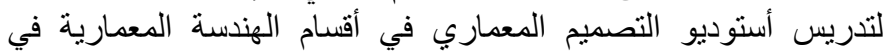

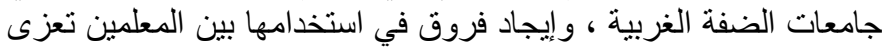

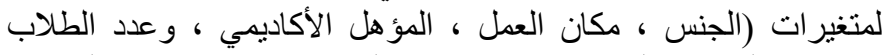

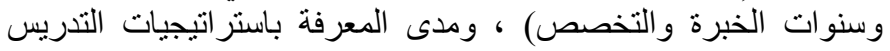

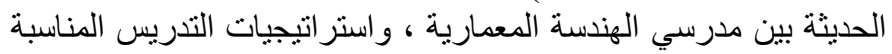
لتدريس استوديو التصميم لكل مستوى من مستويات الدر اسة. تكمن أهمية

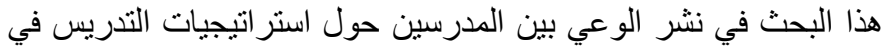

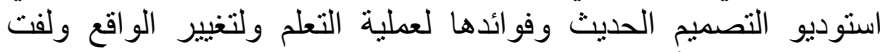
الانتباه إلى علم أصول التدريس في استوديو التصميم المعماري الجديد.

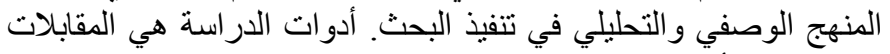

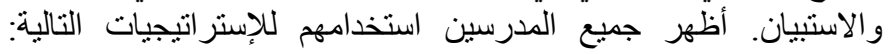
إستراتيجية العصف الذهني ، إسنراتيجية حل المشكلات ، إستراتيجية

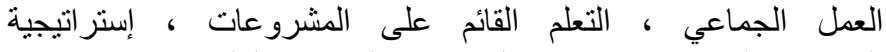
المحاضر (المطورة) ، وطريقة الرحلات و الزيار ات العلمية. 